\title{
Sorption isotherms and kinetics of chromium uptake from wastewater using natural sorbent material
}

\author{
${ }^{1 *}$ B. A. Shah; ${ }^{2}$ A. V. Shah; ${ }^{1}$ R. R. Singh \\ ${ }^{1}$ Department of Chemistry, Veer Narmad South Gujarat University, Surat, Gujarat, India \\ ${ }^{2}$ Science and Humanities Department, Polytechnic College, Vidhya Bharti Trust, Umrakh, Bardoli, Gujarat, India \\ Received 13 May 2008; $\quad$ revised 28 September 2008; accepted 25 November 2008; available online 10 December 2008
}

\begin{abstract}
Chromium (VI) which exists in many industrial wastewater is considered highly toxic. The aim of the present investigation was to study the reduction of chromium (VI) to chromium (III) and then removing it with the help of weathered basalt andesite products. Reduction of the chromium (VI) to chromium (III) by hydrazinium sulfate was investigated. The influence of hydronium ion concentration, contact time, hydrazinium sulphate dosage and temperature has been tested in batch runs. The process was found to be acid, temperature and concentration dependent. The suitability of weathered basalt andesite products as a potential sorbent was assessed for the removal of chromium (III) following batch mode of operation. The effect of various parameters such as hydronium ion concentration, shaking time, sorbent dose, initial metal ion concentration and temperature on the removal of chromium (III) from aqueous solution was studied. Thermodynamic parameters $\left(\Delta \mathrm{H}^{\circ}, \Delta \mathrm{S}^{\circ}\right.$ and $\left.\Delta \mathrm{G}^{\circ}\right)$ for the sorption process were evaluated. Analysis of sorption obtained results showed that the sorption pattern followed the Freundlich, Langmuir and Dubinin-KaganerRadushkevich isotherms. The process follows pseudo second order rate and surface diffusion is identified as the predominating mechanism. The sorption process was shown to be reversible by the recovery of sorbed chromium (III) upon extraction with $0.5 \mathrm{M}$ nitric acid. The sorbent, before and after sorption, was characterized by fourier transform infrared spectrometer, X-ray diffraction, scanning electron microscope, transmision electron microscope and thermogravimetric analyse methodes. An increase in crystallanity after sorption of chromium was observed. An industrial effluent was successfully treated with the same sorbent with convincing results.
\end{abstract}

Key words: Weathered basalt andesite products, reduction of chromium (VI), hydrazinium sulfate

\section{INTRODUCTION}

Chromium has extensive use in industrial applications such as metal finishing, leather tanning, pigment products, textiles, magnetic tapes, wood preservation and corrosion control agents in cooling waters, etc. (Kirk and Othmer, 1994). In nature, chromium exists in numerous oxidation states between -2 to +6 , but only chromium (III) and chromium (VI) are stable. Chromium (VI) is highly mobile and toxic and also form most widely presents in industrial wastewaters (Cielslak-Golonka, 1995). Through refuse wastewater, chromium enters especially into freshwater or soil and thereby into plant, animals and human beings. Chromium is non biodegradable and toxic beyond a given concentration. Chromium threshold concentration on inhibitory effect on heterotrophic organisms is $10 \mathrm{mg} / \mathrm{L}$ for chromium (III) and $1 \mathrm{mg} / \mathrm{L}$ for chromium (VI). All living organisms require varying

*Corresponding Author Email: bhavna606@yahoo.co.in Tel.: +261 221 1826; Fax: +262 2225458 amount of chromium (III) in micro amount for proper functioning. Chromium (VI) is considered by International Agency for Research on Cancer (IARC) as a powerful carcinogen that modifies the deoxyribonucleic acid (DNA) transcription process causing important chromosomic aberration (USHHS, 1991). Chromium (VI) is known to cause various health effects such as skin rashes, upset stomach and ulcers, respiratory problems, weakened immune system, kidney and liver damage, alteration of genetic material, lung cancer and also death (HDR Engineering Inc., 2001). Chromium is not known to be accumulate in the bodies of fish, but high concentrations of chromium due to the disposal of metal products in surface waters can damage the gills of fish that swim near the point of disposal. In animals, chromium can cause respiratory problems, infertility and tumor, formation a lower ability to fight against disease and birth defects. Maximum contaminant level for chromium set by Environmental 
Protection Agency (EPA) drinking water standard is $0.1 \mathrm{mg} / \mathrm{L}$ (USEPA, 2003). World health organization recommended the maximum allowable concentration of $0.05 \mathrm{mg} / \mathrm{L}$ in drinking water for chromium (VI). According to the Indian Standard Institution, the desirable limit for chromium as chromium (VI) in drinking water is $0.05 \mathrm{mg} / \mathrm{L}$. As per Indian Standard Institution, the tolerance limit for discharge of chromium containing wastewater in inland surface water, public sewers and marine/coastal areas is 2.0 mg/L (Indian Standards, 1993). As per studies carried out, chromium (VI) is 500 times more toxic to chromium (III) (Kowalski, 1994). As a consequence of the dramatic difference in the physical and chemical properties of two chromium types and benign character of chromium (III), the reduction of chromium (VI) to chromium (III) may be considered as a satisfactory solution. Reduction to chromium (III) is advantageous as it makes the removal and recovery by natural sorbents. The reducing agents commonly used for hexavalent chromium are sodium sulfite and ferrous sulfate (Eckenfelder, 1989). A number of iron based reductants are waste shot blast fines (Ghiassi and Smith, 2006), iron sulfide (Erdem et al., 2001), scrap iron (Gheju and Lovi, 2006) and siderite (Erdem et al., 2004). Li and Wang (2004) used sucrose and starch for the reduction. Bhargava and Guha, (2005) utilized zero valent iron in conjunction with sulfate reducing bacteria for the conversion of chromium (VI) to chromium (III). Ekenberg et al. (2005) studied the probability of chromium (VI) reduction by anaerobic biological treatment in biofilm process. Baeam et al. (2000) and Choudhary et al. (2003) investigated clay minerals for the reduction of hexavalent chromium. Aware of the importance of Integrated waste management, the authors of this study are involved in research concerning the removal and recovery of heavy metals from the wastewater (Shah et al., 2003, 2004, 2006 and 2007). It is strongly believed that finding costly effective environmentally friendly methods for the reduction of chromium (VI) from industrial wastewater requires further investigation. All the above mentioned research for chromium (VI) introduces other ions, thereby increasing the dissolved solids and making the sorption process more complicated which is proven as an economical process for the removal and recovery of metal ions in developing countries. Therefore, the reduction of chromium (VI) by cheap and environmental friendly hydrazinium sulfate (HS) was studied. For this purpose, batch experiments were conducted to study the parameters such as hydronium ion concentration, initial chromium (VI) concentration, HS dosage, equilibrium time and temperature. Reduction of chromium (VI) to chromium (III) is not the ultimate solution as chromium (III) can be oxidized to the more mutagenic chromium (VI) by $\mathrm{MnO}_{2}$ in the environment or by some bacteria in soil under proper conditions (Han et al., 2006). Therefore, Weathered basalt andesite products (WBAP), a simple effective and economical sorbent was utilized for removal of chromium (III) from the wastewater. The wastewater of the electroplating industry $\mathrm{M} / \mathrm{s}$ excel shine private limited situated at Valsad was sampled during January 2003 to December 2003.

\section{MATERIALS AND METHODS}

WBAP, gray in color, was obtained from weathered basalt deposit in Kutch region of Gujarat (India). This material was first treated with $\mathrm{H}_{2} \mathrm{O}_{2}$ at room temperature for $24 \mathrm{~h}$ to oxidize the adhering organic matter and washed with demineralized water. Preliminary sorption studies revealed that heating the sorbent at $100{ }^{\circ} \mathrm{C}$ retards the sorption characteristics; therefore, WBAP was dried in open atmosphere and then stored in a polypropylene container in a desiccator. No other physical or chemical treatments were used prior to sorption experiment. Demineralized water with conductivity $1.0 \mu \mathrm{S} / \mathrm{cm}$ was used after distillation. The chemicals used in the investigation were supplied by Rankem as analytical grade reagents. Synthetic stock solution (1000 ppm) of chromium (VI) was prepared using potassium dichromate dried at $378 \mathrm{~K}$ for $24 \mathrm{~h}$ in demineralized water. $0.25 \mathrm{M}$ solution of hydrazinium suphate (HS) was prepared by dissolving $\mathrm{NH}_{2} \mathrm{NH}_{2} \cdot \mathrm{H}_{2} \mathrm{SO}_{4}(98.5 \%)$ in $1 \mathrm{~L}$ demineralized water. Solutions with different $\mathrm{Cr}$ (III) concentrations were prepared from reagent grade nitrate salt in demineralized water. Their $\mathrm{pH}$ values were adjusted to the predetermined values adding small quantities of concentrated $\mathrm{HNO}_{3}$ or $\mathrm{NaOH}$ solution and confirmed by $\mathrm{pH}$ measurements. The $\mathrm{Cr}$ bearing wastewater samples were collected from electroplating unit situated at Valsad, M/s. excel shine private limited. It has four major sections: Electro less nickel plating section; copper plating section; chrome plating section; other pretreating sections. The highest chromium concentration was found to be 90 $\mathrm{mg} / \mathrm{L}$ and $\mathrm{pH}$ 1.0- 3.0. The $\mathrm{pH}$ of all solutions was 
measured on Systronics (instrument model 361) pH meter. The concentration of metal ion was analyzed using Hach DR/2500 spectrophotometer after 1:10 dilution (APHA, 1992). The infrared (IR) spectra of the samples were recorded on thermo-nicolet nexus fourier transform infrared (FT-IR) spectrometer. SEM images were acquired using a LEO 435 VP scanning electron microscope (LEO Electron Microscopy Ltd., Cambridge, England) operating at $15 \mathrm{kV}$. Philips EM400 transmission electron microscope (Einhoven, The Netherlands) with a maximum accelerating voltage of $120 \mathrm{kV}$ was employed to obtain the high resolution images and selected-area electron diffraction (SAED) patterns . X-ray diffraction patterns of the sample were recorded on a Bruker AXS D8 advance diffractometer employing copper-K $\mathrm{K}_{\alpha}(\lambda=1.54060 \AA)$ radiations and nickel filter at $40 \mathrm{kV}$ to record a pattern in the $2 \theta$ range of 5 - 1200. The thermal analysis of the samples were performed using a Perkin Elmer Pyris Diamond TG/TGA instrument at a fixed heating rate of $10^{\circ} \mathrm{C} / \mathrm{min}$ over a temperature range of $26-1000^{\circ} \mathrm{C}$ using alumina powder (10 mg) as reference. The degradation runs were taken under oxidizing atmosphere (flowing dry air) at a flow rate of $200 \mathrm{~mL} / \mathrm{min}$. The density of the sorbent was determined by specific gravity bottles. The sorption experiment were studied by batch technique using laboratory scale stirred tank reactors (STR) equipped with six glass vessel of $1 \mathrm{~L}$ and twin blade impeller driven by a variable speed motor. Pre weighed sample of the sorbent and a measured volume of chromium (III) solution were taken in $1 \mathrm{~L}$ glass vessel of STR and the mixture was agitated for a constant time. The impeller speed was set at $100 \mathrm{rpm}$. At increasing time intervals, aliquots of sample were withdrawn by plastic syringe filtered and after dilution of 1:10 analyzed using Hach spectrophotometer.

\section{RESULTS AND DISCUSSION}

\section{Characterization of WBAP}

Chemical constituents of the WBAP as determined by standard methods of chemical analysis (Burgess et al., 1987; Vogel, 1989) are $\mathrm{SiO}_{2}, 55.09 \% ; \mathrm{Al}_{2} \mathrm{O}_{3}, 10.48$ \%; $\mathrm{Fe}_{2} \mathrm{O}_{3}, 13.32 \%$; $\mathrm{CaO}, 4.80 \%$; $\mathrm{Na}_{2} \mathrm{O}, 2.46 \%$; $\mathrm{K}_{2} \mathrm{O}$, $0.19 \%$; loss on ignition, $16.88 \%$ by weight. Two gram sample of WBAP was stirred with demineralized water (100 mL, pH 6.59) for $24 \mathrm{~h}$ in an air tight stoppered conical flask. An enhancement in $\mathrm{pH}$ up to 9.66 was noticed. It is quite stable in water, salt solution, acids and bases.
The X-ray diffraction pattern of the sorbent (Fig. 1) provided d-spacing values which reflect the presence of Illite (4.447, 3.3466, 2.5704, 9.698, 2.455, $1.4928 \AA$ ), Montmorillonite (14.859, 4.447, 3.06, $1.4928 \AA$ ), Paragonite / Mica (2.515, 3.1915, 9.6985 $\AA$ ), tetrakalsilite (3.0697, 2.8969, 4.447 А), Faujasite (14.859, 3.1915, 2.51 $\AA$ ), Kaolinite (7.23302, $3.52494 \AA$ ) and Geothite (2.4555 Å) indicating a high chemical stability (JCPDS, 1971). After sorption, the change in diffraction pattern is clearly noticeable and new diffraction pattern is observed in the region of 10 to 60 Theta scale. The original WBAP has a d-spacing of $14.859 \AA$ which increased to 15.112 because of expansion in the interlayer spacing.

The scanning electron microscope (SEM) photograph indicates WBAP to be highly porous which is in agreement with the porosity value (0.438 fraction). SEM micrographs before and after sorption process (Figs. $2 \mathrm{a}$ and $\mathrm{b}$ ) show accumulation of contaminent on sorbed WBAP. A horizontal layer type of sorption is observed on the smooth surface, whereas accumulation of contaminants on the edges of the rough surfaces, as well as in the macropores is observed. The images also indicate towards the possibility of multilayer sorption. After sorption, the WBAP particles seem to be more fluffy and porous. This may be due to the change in surface charge of the particle as a result of introduction of chromium (III) ions.

Transmision electron microscope (TEM) photographs (Figs. $3 \mathrm{a}$ and b) of WBAP-chromium show increase in electron density which is distinctly seen in SEAD with concentric rings (Figs. $3 \mathrm{c}$ and d).

The DTA- thermo-gravimetric analyse (TGA) curves (Fig. 4) indicate first loss of weight (6.7 \%) between 25 and $125{ }^{\circ} \mathrm{C}$. These transformations are due to the removal of adsorbed water between the silicate sheets. The differential thermal (DTA) curve shows the process to be endothermic. A small endothermic peak between $225-290{ }^{\circ} \mathrm{C}$ is observed which corresponds to loss of interlayer water molecules $(1.04 \%)$. The third loss of weight (7\%) takes place between $370-500{ }^{\circ} \mathrm{C}$ and is completed at $750{ }^{\circ} \mathrm{C}$ due to loss of structural water, i.e. the hydroxyl groups from the WBAP. This step is also endothermic in nature. Further heating does not show any change. The kinetic parameters for these decomposition steps were evaluated by Coats and Redfern method (Coats and Redfern, 1964). The value of energy of activation (E) and pre-exponential factor (A) was calculated from 
Sorption isotherms and kinetics of chromium(III)
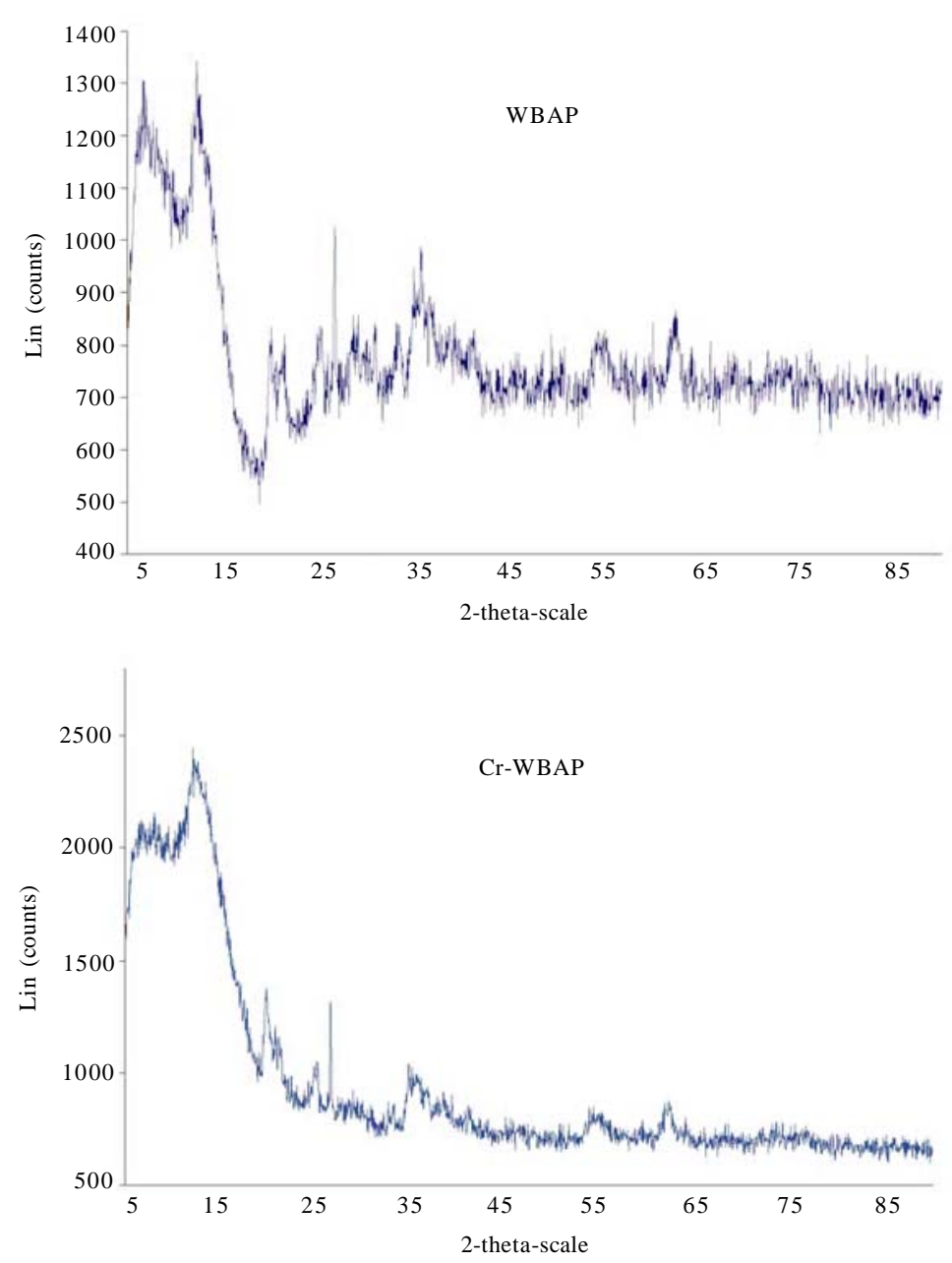

Fig. 1: Power x-ray diffraction (PXRD) pattern of WBAP and chromium sorbed WBAP

(a)

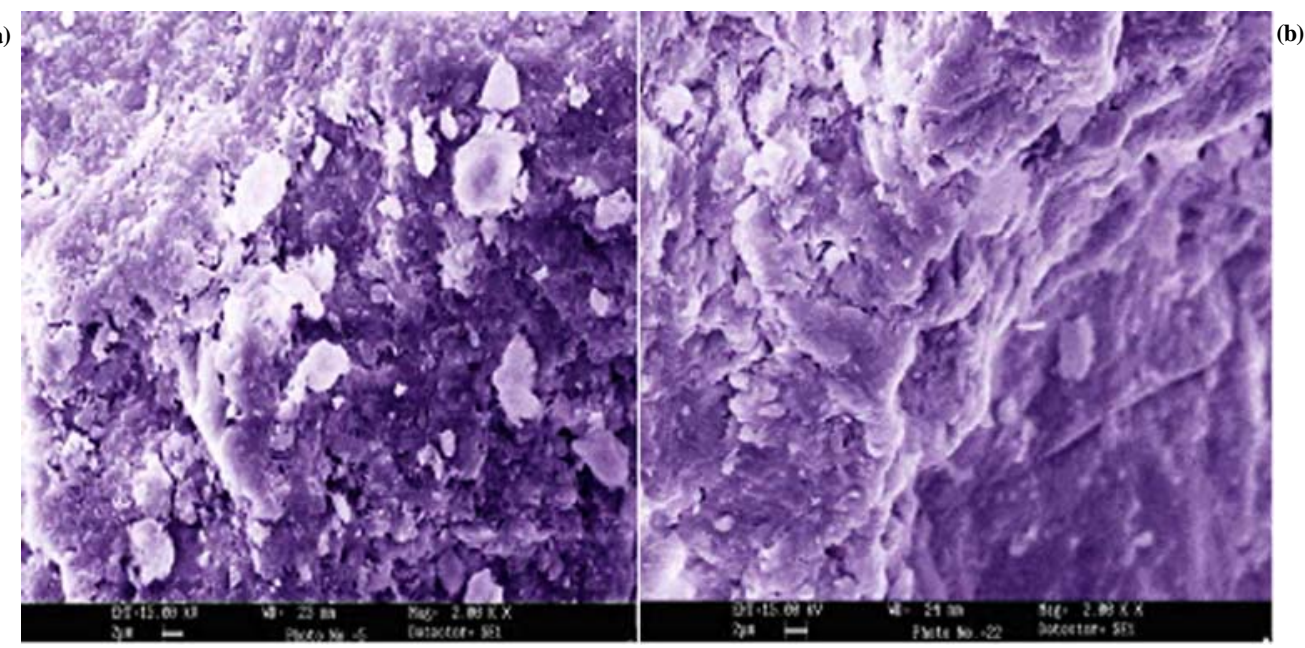

Fig. 2: SEM micrographs of (a) WBAP and (b) WBAP-chromium at $2000 \mathrm{X}$ magnification 

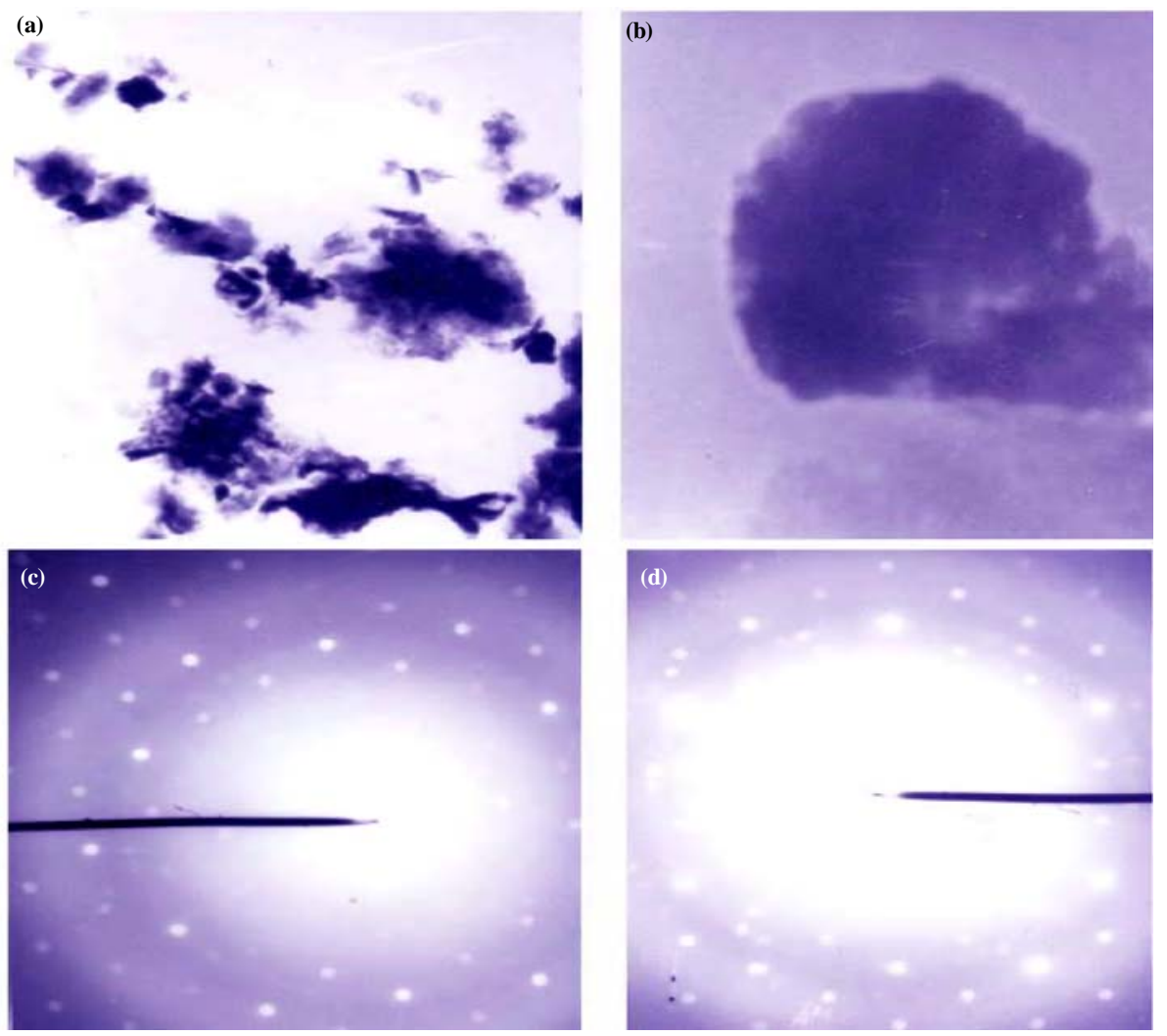

Fig. 3: TEM photographs of chromium-WBAP: (a) 3500 X (b) 4500 X (c- d) SAED image

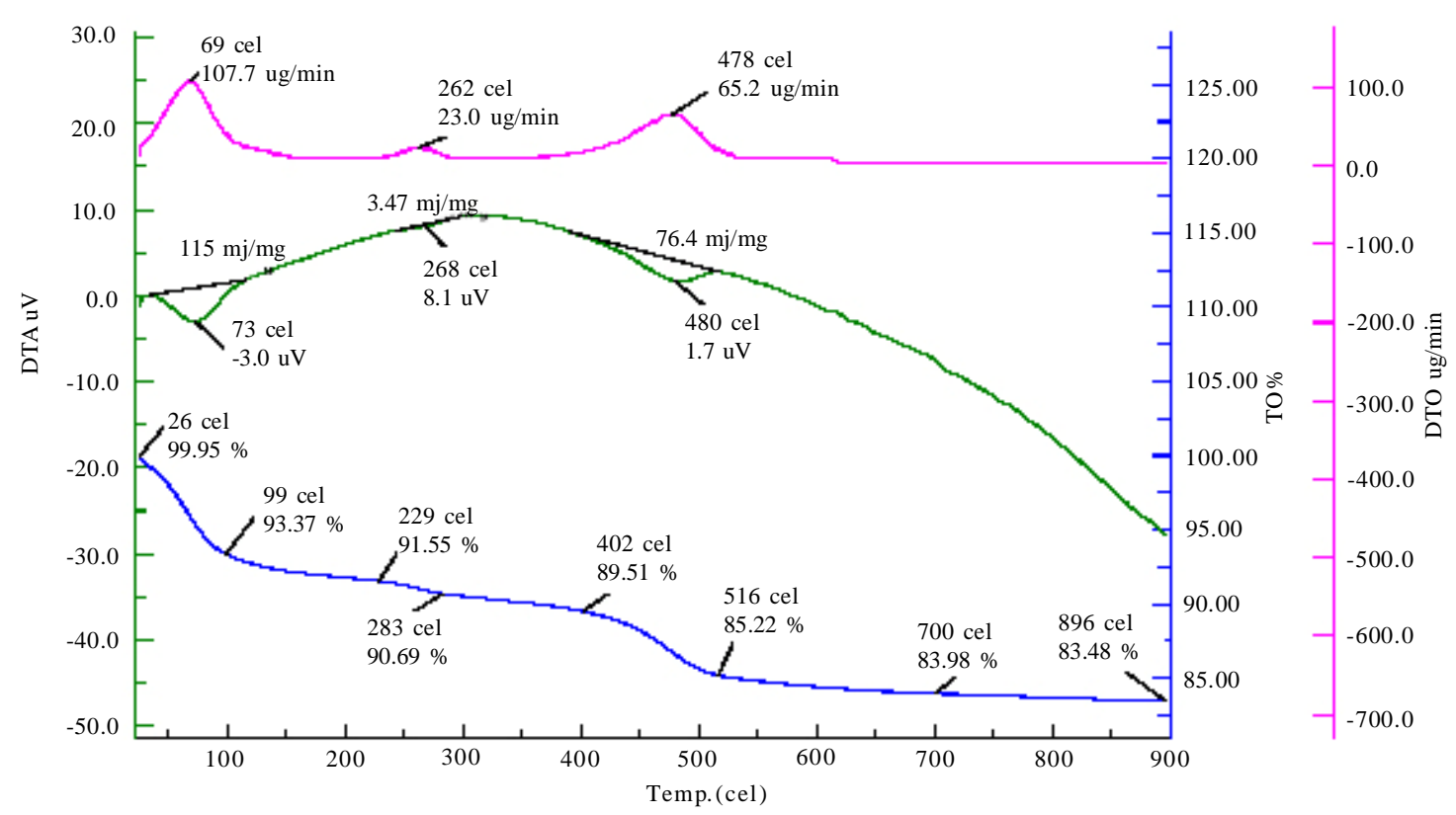

Fig. 4: TGA, DTA and differential scanning calorimetry (DSC) curves of chromium-WBAP 
Table 1: Kinetic data of the thermal decomposition of the sorbent

\begin{tabular}{llr}
\hline $\begin{array}{l}\text { Step of } \\
\text { degradation }\end{array}$ & Parameters & \multicolumn{1}{c}{ Result } \\
\hline & Order of decomposition & 2 \\
Step 1 & $\mathrm{E}^{*}(\mathrm{~kJ} / \mathrm{mol})$ & 64.2636 \\
$\left(30-110^{\circ} \mathrm{C}\right)$ & $\mathrm{A}\left(\mathrm{S}^{-1}\right)$ & $7.0736 \times 10^{8}$ \\
& $\mathrm{~S}^{*}(\mathrm{~J} / \mathrm{K} / \mathrm{mol})$ & -76.507 \\
& $\mathrm{H}^{*}(\mathrm{~kJ} / \mathrm{mol})$ & 61.469 \\
& $\mathrm{G}^{*}(\mathrm{~kJ} / \mathrm{mol})$ & 87.1818 \\
& Order of decomposition $^{*}$ & $3 / 2$ \\
& $\mathrm{E}^{*}(\mathrm{~kJ} / \mathrm{mol})$ & 121.145 \\
Step 2 & $\mathrm{A}^{\left(\mathrm{S}^{-1}\right)}$ & $3.212 \times 10^{10}$ \\
$\left(210-290^{\circ} \mathrm{C}\right)$ & $\mathrm{S}^{*}(\mathrm{j} / \mathrm{K} / \mathrm{mol})$ & -48.652 \\
& $\mathrm{H}^{*}(\mathrm{~kJ} / \mathrm{mol})$ & 116.689 \\
& $\mathrm{G}^{*}(\mathrm{~kJ} / \mathrm{mol})$ & 142.761 \\
& $\mathrm{Order} \mathrm{of} \mathrm{decomposition}^{*}$ & $3 / 2$ \\
& $\mathrm{E}^{*}(\mathrm{~kJ} / \mathrm{mol})$ & 142.557 \\
Step 3 & $\mathrm{A}\left(\mathrm{S}^{-1}\right)$ & $2.697 \times 10^{8}$ \\
$\left(370-530{ }^{\circ} \mathrm{C}\right)$ & $\mathrm{S}^{*}(\mathrm{j} / \mathrm{K} / \mathrm{mol})$ & -33.669 \\
& $\mathrm{H}^{*}(\mathrm{~kJ} / \mathrm{mol})$ & 136.382 \\
& $\mathrm{G}^{*}(\mathrm{~kJ} / \mathrm{mol})$ & 161.387 \\
\hline
\end{tabular}

the slope and intercept of the best fit curve (Not shown). Following equations were employed to calculate the entropy of activation (Eq. 1), the enthalpy of activation (Eq. 2) and free energy of activation (Eq. 3):

$$
\begin{aligned}
\mathrm{S}^{*} & =2.303[\log (\mathrm{Ah} / \mathrm{KT})] \mathrm{R} \\
\mathrm{H}^{*} & =\mathrm{E}^{*}-\mathrm{RT} \\
\mathrm{G}^{*} & =\mathrm{H}-\mathrm{TS}
\end{aligned}
$$

Where, $\mathrm{h}$ and K are Planck's and Boltzmann constants, respectively. The data is given in Table 1 . The negative value of $S^{*}$ and positive value of $G^{*}$ indicate that the decomposition reaction is slow.

The surface area was found to be $618.25 \mathrm{~m}^{2} / \mathrm{g}$. The point of zero charge was determined by potentiometric titration method (Bhanot et al., 1984). The characteristics of the sorbent are pHzpc 2.4, density $1.16 \mathrm{~g} / \mathrm{cm}^{3}$, porosity 0.4378 fraction and void ratio 0.779 .

\section{Reduction of hexavalent chromium}

Effect of hydronium ion concentration and equilibrium time

Hydronium ions play an important role in the reaction mechanism. Therefore, the effect was investigated in the range of 0.5 to $3.0 \mathrm{pH}$. The study was limited to $\mathrm{pH}$ 3.0 considering the $\mathrm{pH}$ of electroplating industry wastewater $\mathrm{pH}$. Also, during the preliminary experiments, it was observed that precipitation of $\mathrm{Cr}$ (III) as $\mathrm{Cr}(\mathrm{OH})_{3}$ takes place above that which is not appropriate for the recovery of the metal using sorption /ion exchange process. The effect of hydronium ion on the reduction process was studied with $520 \mathrm{mg} / \mathrm{L}$ of chromium (VI) solution and $0.02 \mathrm{M} \mathrm{HS}$ at $295 \mathrm{~K}$. This concentration was selected as it was the maximum concentration for the electroplating wastewater under study. Fig. 5 shows $\mathrm{Cr}$ (VI) reduction percentage as a function of $\mathrm{pH}$ and contact duration. Fig. 5 indicates that the $\mathrm{Cr}(\mathrm{VI})$ reduction was very fast up to $\mathrm{pH} 1.5$, when hexavalent chromium was completely reduced to trivalent form (98.98 \%) within 15 min of reaction time. The conversion is significantly slower for $\mathrm{pH} 2.0$ and above for which $180 \mathrm{~min}$ are required to achieve $98 \%$

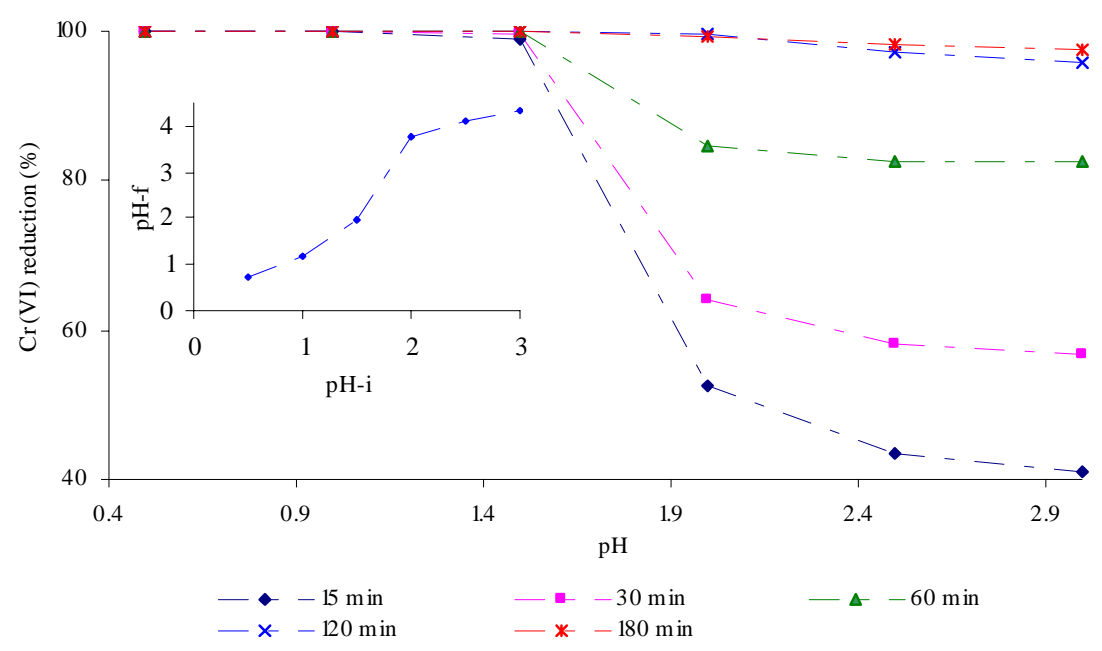

Fig. 5: Effect of initial $\mathrm{pH}$ on the reduction of chromium (VI). The embedded figure represents the change in final $\mathrm{pH}$ after $420 \mathrm{~min}$ of equilibrium 
conversion. This higher rate of reduction at low pH can be explained by considering the following equation:

Reduction $\mathrm{Cr}_{2} \mathrm{O}_{7}^{-2}+14 \mathrm{H}^{+}+6 \mathrm{e}^{-} \rightarrow 2 \mathrm{Cr}^{+3}+7 \mathrm{H}_{2} \mathrm{O}$

Oxidation $\mathrm{N}_{2} \mathrm{H}_{4} \rightarrow \mathrm{N}_{2}+4 \mathrm{H}^{+}+4 \mathrm{e}^{-}$

Over all reaction $2 \mathrm{Cr}_{2} \mathrm{O}_{7}^{-2}+3 \mathrm{~N}_{2} \mathrm{H}_{4}+16 \mathrm{H}^{+} \rightarrow 4 \mathrm{Cr}^{+3}+$ $3 \mathrm{~N}_{2}+14 \mathrm{H}_{2} \mathrm{O}$

The increase in reduction at low $\mathrm{pH}$ is due to the stress imposed due to higher $\mathrm{H}^{+}$ions. Also, an increase in $\mathrm{pH}$ value was observed (embedded in Fig 5) that may be due to the consumption of hydronium ions during the reduction process.

\section{Effect of HS dosage}

The effect of HS dosage on reduction of chromium (VI) was studied. The effect of the molar ratio of chromium (VI) to HS at pH 2.20 and temperature $295 \mathrm{~K}$ was observed. With increase in HS dosage from 1:1 to 1:6 (chromium:HS) molar ratio, the reduction percentage of chromium (VI) increases. The molar ratio of 1:1 is insufficient to complete the reduction of chromium (VI) within $120 \mathrm{~min}$ which is in accordance with equation 3. With molar ratio $1: 2$, it was possible to achieve $98 \%$ reduction of chromium (VI) and $99.9 \%$ reduction of chromium (VI) was achieved with molar ratio 1:3 and above within 30 min of reaction time. An increase in final $\mathrm{pH}$ was observed with the reduction process.

\section{Effect of temperature}

The effect of temperature on the reduction of hexavalent chromium was investigated at 278, 295 and $315 \mathrm{~K}$ for chromium (VI)/HS molar ratio $1 / 2$ and initial $\mathrm{pH}$ 2.3. The results indicate that higher temperature favors the reduction of chromium (VI). The reduction was found to be completed in about $30 \mathrm{~min}$ at temperature $315 \mathrm{~K}$ and above. With the temperature $295 \mathrm{~K}$, the reduction of $98.6 \%$ was achieved in $120 \mathrm{~min}$. Each rise of $20 \mathrm{~K}$ temperature reduces the reaction time required about $90 \mathrm{~min}$ for the complete reduction. It can be concluded that the reduction process of chromium (VI) by HS is endothermic.

Study of reaction order with respect to chromium (VI) The first order reaction is:

$\log \left[A_{e}-A_{t}\right]=\log A_{e}-\left(K_{f} \cdot t\right) / 2.303$

Where, $\left[\mathrm{A}_{\mathrm{t}}\right]$ is the concentration of chromium (VI) reduced to chromium (III) at time $t(\mathrm{mg} / \mathrm{L}), \mathrm{K}_{\mathrm{f}}$ is the rate constant of first order model $\left(\mathrm{min}^{-1}\right)$ and $\mathrm{t}$ is the time (min). $A_{e}$ is chromium (III) concentration at equilibrium. Plotting $\log \left[A_{e}\right]-\log \left[A_{t}\right]$ against time creates a straight line with slope $-\mathrm{K}_{\mathrm{f}}$. The plots for the reduction of chromium (VI) were not linear indicating that the reaction order for conversion of chromium (VI) to chromium (III) is not of first order.

The second order rate model can be represented as:

$\mathrm{t} /\left[\mathrm{A}_{\mathrm{t}}\right]=1 / \mathrm{Ks} .\left[\mathrm{A}_{\mathrm{e}}\right]^{2}+\mathrm{t} /\left[\mathrm{A}_{\mathrm{e}}\right]$

Where, $\mathrm{K}_{\mathrm{s}}$ is the rate constant for the second order model ( $\mathrm{M} / \mathrm{min}$.). The plot of $\mathrm{t} /\left[\mathrm{A}_{\mathrm{t}}\right]$ versus time should give a straight line if the reaction is of second order in nature.

The plots for chromium (VI) reduction were found to be linear (Fig. 6a). The regression coefficients for the second order model were fond to be closer to unity $\left(\mathrm{R}^{2}=0.9891-0.9999\right)$. The obtained value of rate constant $\left(\mathrm{K}_{\mathrm{s}}\right)$ was found to be $0.99 \mathrm{M} / \mathrm{min}$., $4.78 \mathrm{M} / \mathrm{min}$ and 66.45 $\mathrm{M} / \mathrm{min}$. for reduction at $278 \mathrm{~K}, 295 \mathrm{~K}$, and $315 \mathrm{~K}$.

The activation energy for the reduction process was determined using Arrhenius equation:

$\ln \mathrm{K}=-\mathrm{E}_{\mathrm{a}} / \mathrm{RT}+\ln \mathrm{A}$

Where, $\mathrm{E}_{\mathrm{a}}$ is activation energy, $\mathrm{R}$ is the gas constant (8.314 J/mol.K), $\mathrm{T}$ is absolute temperature in Kelvin and $\mathrm{A}$ is frequency factor.

$\mathrm{A}=\mathrm{p} \cdot \mathrm{Z}$,

Where, $\mathrm{Z}$ is the collision rate and $\mathrm{p}$ is steric factor. $\mathrm{Z}$ turns out to be only weakly dependent on temperature. Thus, the frequency factor is constant, an specific for each reaction. The plot of $\ln \mathrm{K}$ versus $1 / \mathrm{T}$ yields a straight line with slope equals to $-\mathrm{E}_{\mathrm{a}} / \mathrm{R}$. The activation energy of chromium (VI) reduction was calculated from Fig. $6 \mathrm{~b}$ and comes out to be $83.93 \mathrm{~kJ} / \mathrm{mol}$.

\section{Potential industrial application}

The wastewater from the electroplating industry with initial $\mathrm{pH} 1.44$ and chromium (VI) concentration $180 \mathrm{mg} / \mathrm{L}$ was treated with HS in the 1:2.5, 1:5 and 1:10 molar ratio. The reduction was almost completed in 15- 30 min of contact duration.

\section{Sorption of trivalent chromium by WBAP \\ Effect of hydronium ion}

$\mathrm{PH}$ is one of the most important parameter controlling uptake of heavy metals from wastewater and aqueous solutions by charged surfaces through 
Sorption isotherms and kinetics of chromium(III)

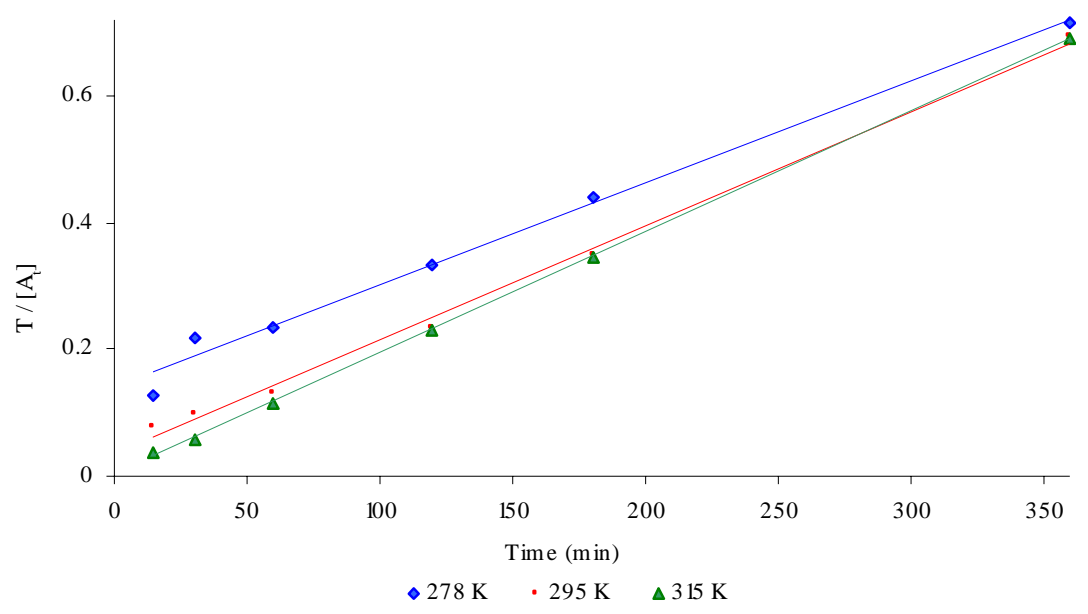

Fig. 6a: Second order kinetic plot for the reduction of chromium (VI)

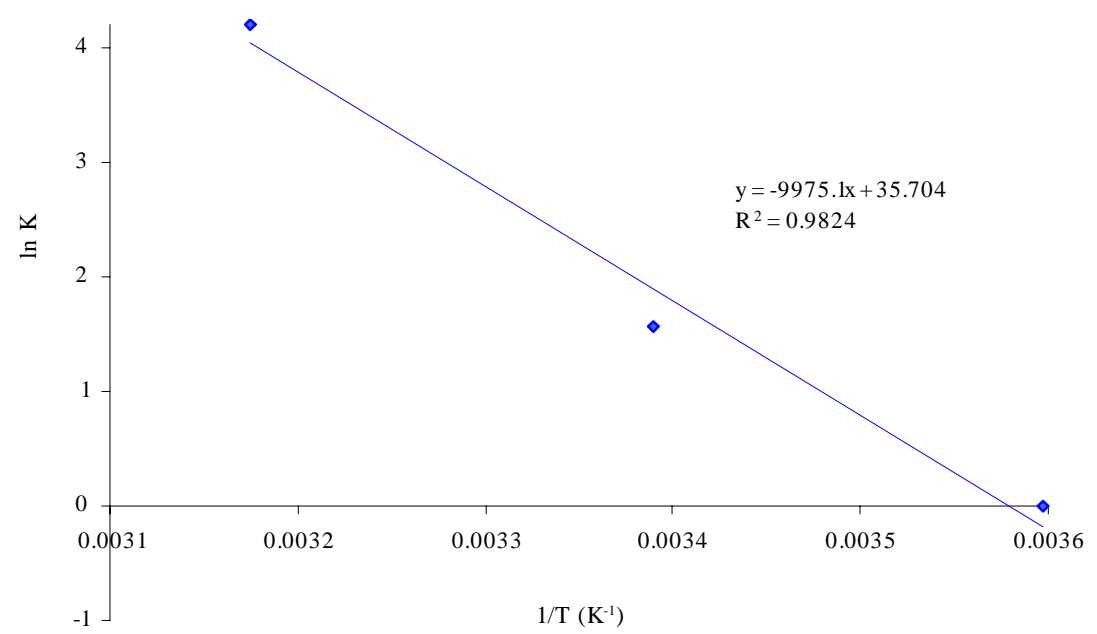

Fig. $6 \mathrm{~b}$ : $\ln \mathrm{K}$ versus $1 / \mathrm{T}$ plot for the reduction of chromium (VI)

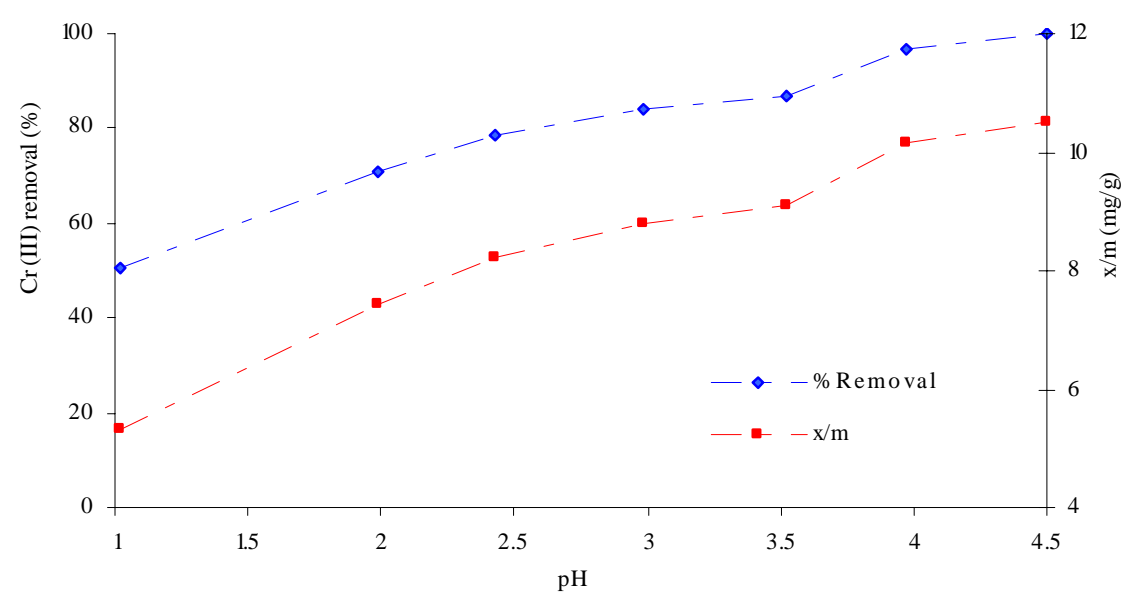

Fig. 7: Effect of $\mathrm{pH}$ on the sorption of chromium (III) on the activated WBAP 
control over the ionization of surface functional groups, the degree of ionization and the speciation of the sorbate species (Krieg et al., 2001). Sorption of chromium (III) was determined over the $\mathrm{pH}$ range of 1 to 4.5 . The $\mathrm{pH}$ study was limited to value equal to 4.5 because precipitation was observed after that. The study was carried out with initial concentration of $210 \mathrm{mg} / \mathrm{L}$ chromium (III) and $20 \mathrm{~g} / \mathrm{L}$ WBAP dosage at $295 \mathrm{~K}$ and $100 \mathrm{rpm}$ stirring. From Fig. 7, it was concluded that the uptake was almost constant between $\mathrm{pH} 3$ to 3.5. The drastic increase in removal at $\mathrm{pH} 4.0$ may be due to the precipitation of chromium (III) as $\mathrm{Cr}(\mathrm{OH})_{3}$ and not due to sorption. The increase in sorption as the $\mathrm{pH}$ increases, can be explained on the basis of decrease in competition between proton and the metal cations for the same functional group and by the decrease in positive surface charge which results in a lower electrostatic repulsion between the surface and the metal ions. The variation in the removal of various metal ions can be explained by considering the surface charge of the WBAP. The composite ZPC of the sorbent is found to be 2.4. Thus, below $\mathrm{pH}$ of 2.4, the surface will have high positive charge density and under these conditions the uptake of chromium ions would be quite low due to electrostatic repulsion. With increasing $\mathrm{pH}$, i.e beyond ZPC, the negative charge on the surface of sorbent increases, thereby resulting in a sudden enhancement in sorption as such chromium (III) gets sorbed at $\mathrm{pH}$ $>2.0$. These findings are also supported by considering the composition of activated WBAP texture. It is composed of clay minerals having negative double layer at the planar surface and on the broken edges (Van Olphen, 1963), the polarity of the double layer reversed, i.e. the fixed part of the double layer is positive and the counter ions are anions. The positive double layer at broken edges changes polarity with $\mathrm{pH}$ and results in an enhancement of negative sorption sites at higher $\mathrm{pH}$. Thus, an improved sorption of chromium ions on the sorbent at low $\mathrm{pH}$ suggested that the process of metal ion uptake is sufficient energetic to overcome the net electrostatic repulsion. Since WBAP is efficient in removing chromium (III) ions from aqueous solution with initial $\mathrm{pH}$ greater than 2 and the final $\mathrm{pH}$ reached to almost neutrality after sorption, it may be interesting choice for use in treatment of very acidic metal contaminated wastewater.

\section{Effect of shaking time}

The variation in removal of chromium (III) with

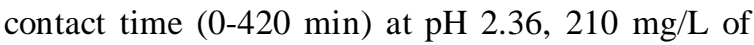
chromium (III) solution, stirring rate $100 \mathrm{rpm}$, temperature $295 \mathrm{~K}$ and sorbent dose $20 \mathrm{~g} / \mathrm{L}$. The rate of uptake is quite rapid in the beginning and typically $70 \%$ ultimate sorption occurs within the first $15 \mathrm{~min}$ of contact duration and concentration of chromium (III) ions becomes asymptotic to time axis after that. Sorption slowed down in later stages due to reduction in the number of vacant surface sites available for sorption and the increase in the repulsive forces between solute molecules of solid and bulk phase. The contact time required for the removal of chromium (III) by WBAP is very short implying this material could be used for the economic removal of chromium (III) from wastewater.

\section{Effect of sorbent dosage}

The study for the sorptive removal of chromium (III) with respect to sorbent dose was done over the range 5-40 g/L, at pH 2.36, temperature $295 \mathrm{~K}$, contact time 60 min, stirring rate $100 \mathrm{rpm}$ and initial chromium (III) concentration 220 ppm. The results shown in Fig. 9 demonstrate that the rate of sorption of chromium (III) ions increases when mass of WBAP increased from 5-30 g/L and attains equilibria. Sorption increases from $36.95 \%$ to $93.86 \%$ while the increase in the removal efficiency on introducing an additional $5 \mathrm{~g} / \mathrm{L}$ WBAP was not so significant. The optimum WBAP dosage was $30 \mathrm{~g} / \mathrm{L}$ for the wastewater under study. It is apparent that the removal percent of chromium (III) increases rapidly with increase in the dose of WBAP due to the greater availability of the sorption sites or surface area.

\section{Effect of initial metal ion concentration}

A given mass of sorbent can sorb only a fixed amount of sorbate. Thus, the initial concentration of sorbate is very important. The effect of initial chromium (III) concentration on sorption was investigated over the concentration range 30-500 $\mathrm{mg} / \mathrm{L}$ at fixed $\mathrm{pH} 2.38$; temperature $298 \mathrm{~K}$; contact time $60 \mathrm{~min}$ and sorbent dose $20 \mathrm{~g} / \mathrm{L}$. At lower initial concentration, sufficient sorption sites are available for sorption of the chromium (III). Therefore, the fractional sorption is independent of initial metal ion concentration. However, at higher concentration, the number of ions is relatively higher compared to availability of sorption 
sites. Hence, the removal percent of chromium ions depends on the initial concentration and decreases with increase in initial concentration. However, the amount of chromium (III) ion sorbed per unit sorbent mass increased with increase in initial concentration due to the difference in the sorbate concentration in bulk and solid phase.

\section{Effect of temperature}

The effect of temperature on the sorption of chromium (III) by WBAP was investigated at concentration $\mathrm{C}_{0}=[100 \mathrm{ppm}, 200 \mathrm{ppm}$ and $300 \mathrm{ppm}]$; temperature $\mathrm{T}=(276,295,313$ and 333$) \mathrm{K} ; \mathrm{pH} 2.38$; stirring rate $100 \mathrm{rpm}$; contact duration $60 \mathrm{~min}$ and sorbent dose $20 \mathrm{~g} / \mathrm{L}$. The thermodynamic parameters were calculated from the slope and intercept of $\ln \mathrm{K}_{\mathrm{d}}$ against $1 / \mathrm{T}$ using the following equation:

$\ln \mathrm{K}_{\mathrm{d}}=\left(\Delta \mathrm{S}^{\circ} / \mathrm{R}\right)-\left(\Delta \mathrm{H}^{\circ} / \mathrm{RT}\right)$

Where, $K_{d}$ is distribution coefficient, $\Delta H^{\circ}, \Delta S^{\circ}, R$ and $\mathrm{T}$ are the enthalpy, entropy, gas constant and temperature in Kelvin, respectively. Gibbs free energy $\left(\Delta \mathrm{G}^{\circ}\right)$ of specific sorption was calculated from the well known equation as follow:

$\Delta \mathrm{G}^{\circ}=\Delta \mathrm{H}^{\circ}-\mathrm{T} . \Delta \mathrm{S}^{\circ}$

The values of thermodynamic parameters for the sorption of chromium ions on WBAP are given in Table 2.

The positive value of $\Delta \mathrm{H}^{\circ}$ confirms the endothermic nature of the overall sorption process. The endothermicity of the heat of sorption may be due to the removal of water molecules from the solid/solution interface and from the sorbing cations. This dehydration process of the ions requires energy. This energy of dehydration supersedes exothermicity of the ions getting attach to the surface. The enthalpy change of sorption suggests the possibility of strong bonding between sorbate and sorbent. The Gibbs free energy indicates the sorption process to be spontaneous in nature more favorable at higher temperature. The positive value of $\Delta S^{\circ}$ shows the increased randomness at the solid/solution interface during the sorption process. The positive value of $\Delta \mathrm{S}^{\circ}$ also suggests some structural changes in the sorbate and the sorbent.

\section{Modeling of the sorption isotherms}

To optimize the design of a sorption system for the sorption of sorbates, it is important to establish the most appropriate correlation for the equilibrium curves. To understand the sorption behavior in solution of metal ions by the sorbent WBAP, Freundlich (Freundlich and Hatfield, 1926), Langmuir (Langmuir, 1918) and Dubinin-Kaganer-Radushkevitch (Krishna et al., 2000) models have been used. These models had been widely used by many workers. The obtained experimental data are commonly well fitted with the Langmuir (Eq. 13), Freundlich (Eq. 14) and DKR (Eq. 15) models.

$$
1 / q_{e}=1 / Q_{0}+1 / Q_{0} \cdot b \cdot C_{e}
$$

Where, $\mathrm{q}_{\mathrm{e}}$ is the sorbed amount (mg/g); $\mathrm{C}_{\mathrm{e}}$ is the equilibrium concentration of the sorbate $(\mathrm{mg} / \mathrm{L})$ and $\mathrm{Q}_{0}$ and $b$ are the Langmuir constants related to maximum sorption capacity and energy of sorption, respectively.

$\log q_{e}=\log K+1 / n \log C_{e}$

Where, $q_{e}$ is the sorbed amount (mg/g); $C_{e}$ is the equilibrium concentration of the sorbate $(\mathrm{mg} / \mathrm{L})$ and $\mathrm{K}$ and $\mathrm{n}$ are Freundlich constants related to sorption capacity and sorption intensity, respectively.

$\ln \mathrm{q}_{\mathrm{e}}=\ln \mathrm{X}_{\mathrm{m}}-\beta \varepsilon^{2}$

Where, $\mathrm{q}_{\mathrm{e}}$ is the sorbed amount $(\mathrm{mg} / \mathrm{g})$; $\mathrm{X}_{\mathrm{m}}$ is dubinin kagaber radushkevich (DKR) monolayer capacity, $\beta$ is the activity coefficient related to mean sorption energy and $\varepsilon$ is Polanyi potential which is equal to

$\varepsilon=\mathrm{RT} \ln \left(1 / \mathrm{C}_{\mathrm{e}}\right)$

Where, $\mathrm{R}$ is gas constant $(\mathrm{J} / \mathrm{K} / \mathrm{mol}), \mathrm{T}$ is temperature (kelvin) and $\mathrm{C}_{\mathrm{e}}$ is the equilibrium concentration of the sorbate $(\mathrm{mg} / \mathrm{L})$. When $\ln \mathrm{q}_{\mathrm{e}}$ is plotted against $\varepsilon^{2}$, a straight line is obtained. The slope of the plot gives the value of $\beta$ and the intercept yields the value of sorption capacity, $X_{m}$. The value of $\beta$ is related to sorption energy, $\mathrm{E}$, via following relationship:

$E=-1 /(-2 \beta)^{1 / 2}$

The linearized form of isotherm models for chromium (III) removal by WBAP can be seen in Figs. 8a and b. The correlation factors and other parameters for Freundlich, Langmuir and DKR isotherm are presented in Table 3. The correlation factors confirm good agreement between theoretical models and experimental results. The correlation coefficients for Freundlich and DKR isotherm are highest. The $1 / \mathrm{n}<<1$ 
Int. J. Environ. Sci. Tech., 6 (1), 77-90, Winter 2009

Table 2: Thermodynamic parameters for the sorption of chromium (III) on WBAP

\begin{tabular}{lllccc}
\hline Concentration of $\mathrm{Cr}^{+3}$ & $\Delta \mathrm{H}^{\circ}(\mathrm{kJ} / \mathrm{mol})$ & $\Delta \mathrm{S}^{\circ}(\mathrm{J} / \mathrm{K} / \mathrm{mol})$ & \multicolumn{2}{c}{$-\Delta \mathrm{G}^{\circ}\left(\mathrm{kJ} / \mathrm{mol}^{2}\right)$} \\
\hline & & & $276 \mathrm{~K}$ & $295 \mathrm{~K}$ & $313 \mathrm{~K}$ \\
$100 \mathrm{mg} / \mathrm{L}$ & 67.90 & 291.256 & 12.486 & 18.020 & 23.263 \\
$200 \mathrm{mg} / \mathrm{L}$ & 54.57 & 236.74 & 10.770 & 15.268 & 19.529 \\
$300 \mathrm{mg} / \mathrm{L}$ & 34.34 & 156.52 & 8.859 & 11.833 & 14.651 \\
\hline
\end{tabular}

indicates that sorption capacity is slightly suppressed at lower equilibrium concentration. This isotherm does not predict any saturation of the sorbent by the sorbate. Thus, infinite surface coverage is predicted mathematically indicating multilayer sorption on the surface. The influence of sorption isotherm shaped to know whether the sorption is favorable or not has been discussed in terms of a dimensionless constant $R_{L}$ referred to as separation factor defined as follow:

$\mathrm{R}_{\mathrm{L}}=1 /\left(1+\mathrm{b} \cdot \mathrm{C}_{0}\right)$

Where, $b$ is Langmuir constant $(\mathrm{L} / \mathrm{mg})$ and $\mathrm{C}_{0}$ the initial concentration $(\mathrm{mg} / \mathrm{L})$ the value of $R_{L}$ was found to be less than 1 .

This indicates a highly favorable sorption. The sorption capacity of Indian WBAP for chromium (III) at $\mathrm{pH} 2.36$ and $295 \mathrm{~K}$ was found to be $12.07 \mathrm{mg} / \mathrm{g}$. The sorption capacity obtained for WBAP was found to be comparable to and in some cases better than the other sorbents and activated carbons as reported by Hasany and Ahmad (2006) for coconut husk (0.949 $\mathrm{mg} / \mathrm{g}$ ); Gode and Phelivan (2007) for b-DAEGsporopollenin resin (1.23 $\mathrm{mg} / \mathrm{gm})$ and CEPsporopollenin resin (133.33 mg/gm); Han et al. (2006) for chlorella miniata (14.73 mg/g); Natale et al. (2006) for char of South African coal (0.285 mg/g) and granular activated carbon (2.21 mg/g); Entezari et al. (2005) for tire rubber $(0.85 \mathrm{mg} / \mathrm{g})$; Meunier et al. (2003) for cocoa schells (2.52 mg/g); Bessiere et al. (2002) for bentonite (4.29 mg/g) and perlite (1.4 mg/g) and Abollino et al. (2002) for Na-montmorillonite $(5.13 \mathrm{mg} / \mathrm{g})$. The numerical value of mean sorption energy (E) from DKR isotherm in the present system was found to be 12.909 $\mathrm{kJ} / \mathrm{mol}$ indicating the sorption process to be of ion exchange in nature. The sorption capacity $\left(\mathrm{X}_{\mathrm{m}}\right)$ was found to be $5.83 \mathrm{mg} / \mathrm{g}$ for chromium (III) which is less than the sorption capacity observed at the Langmuir region. This may be attributed to different assumptions taken into consideration while formulating the isotherms. Moreover, these isotherms were devised to explain the sorption of gases on solid surfaces and
Table 3: Langmuir, Freundlich and DKR parameters of sorption isotherm for Chromium (III) on WBAP

\begin{tabular}{lr}
\hline Parameters & Value \\
\hline Langmuir isotherm & 12.067 \\
$\mathrm{Q}_{0}(\mathrm{mg} / \mathrm{g})$ & 0.05257 \\
$\mathrm{~b}(\mathrm{~L} / \mathrm{mg})$ & 0.9554 \\
$\mathrm{R}^{2}$ & 0.0831 \\
$\mathrm{R}_{\mathrm{L}}$ & \\
Freundlich isotherm & 0.3643 \\
$1 / \mathrm{n}$ & 2.028 \\
$\mathrm{~K}$ & 0.9657 \\
$\mathrm{R}^{2}$ & \\
$\mathrm{DKR}$ isotherm & 5.826 \\
$\mathrm{Xm}(\mathrm{mg} / \mathrm{g})$ & $-0.3 \times 10^{-8}$ \\
$\beta\left(\mathrm{mol} / \mathrm{J}^{2}\right)$ & 12.909 \\
$\mathrm{E}(\mathrm{kJ} / \mathrm{mol})$ & 0.9726 \\
$\mathrm{R}^{2}$ & \\
\hline
\end{tabular}

have further been extended to sorption of metal ions from aqueous solution to solid sorbents. From the regression coefficient values, it was concluded that sorption of chromium (III) ions on WBAP followed Freundlich and DKR isotherm postulates.

\section{Kinetics and rate parameters}

Kinetics is another important aspect in evaluation of sorption as a unit operation. The sorption of chromium (III) from liquid phase to solid phase is normally assumed to be controlled by physicochemical processes. To quantify the extent of uptake in sorption kinetics, pseudo first order (Eq. 7) and pseudo second order (Eq. 8) as cited by Ho and McKay, (1999) were used.

The initial sorption rate, $\mathrm{h}(\mathrm{mg} / \mathrm{g} / \mathrm{min}$.), at $t \rightarrow 0$ is defined as:

$\mathrm{h}=\mathrm{K}_{\mathrm{s}} \cdot \mathrm{q}_{\mathrm{e}}^{2}$

The best fit values of $h, q_{e}$ and $K$ along with correlation coefficients for the pseudo first order and pseudo second order (Fig. 9) models are shown in Table 4. The calculated correlation coefficients are closer to unity for pseudo second order kinetic model than that for the pseudo first order kinetic model. Therefore, the sorption can be approximated more appropriately by the pseudo second order kinetic model for the sorption of chromium (III) by WBAP. 
Sorption isotherms and kinetics of chromium(III)
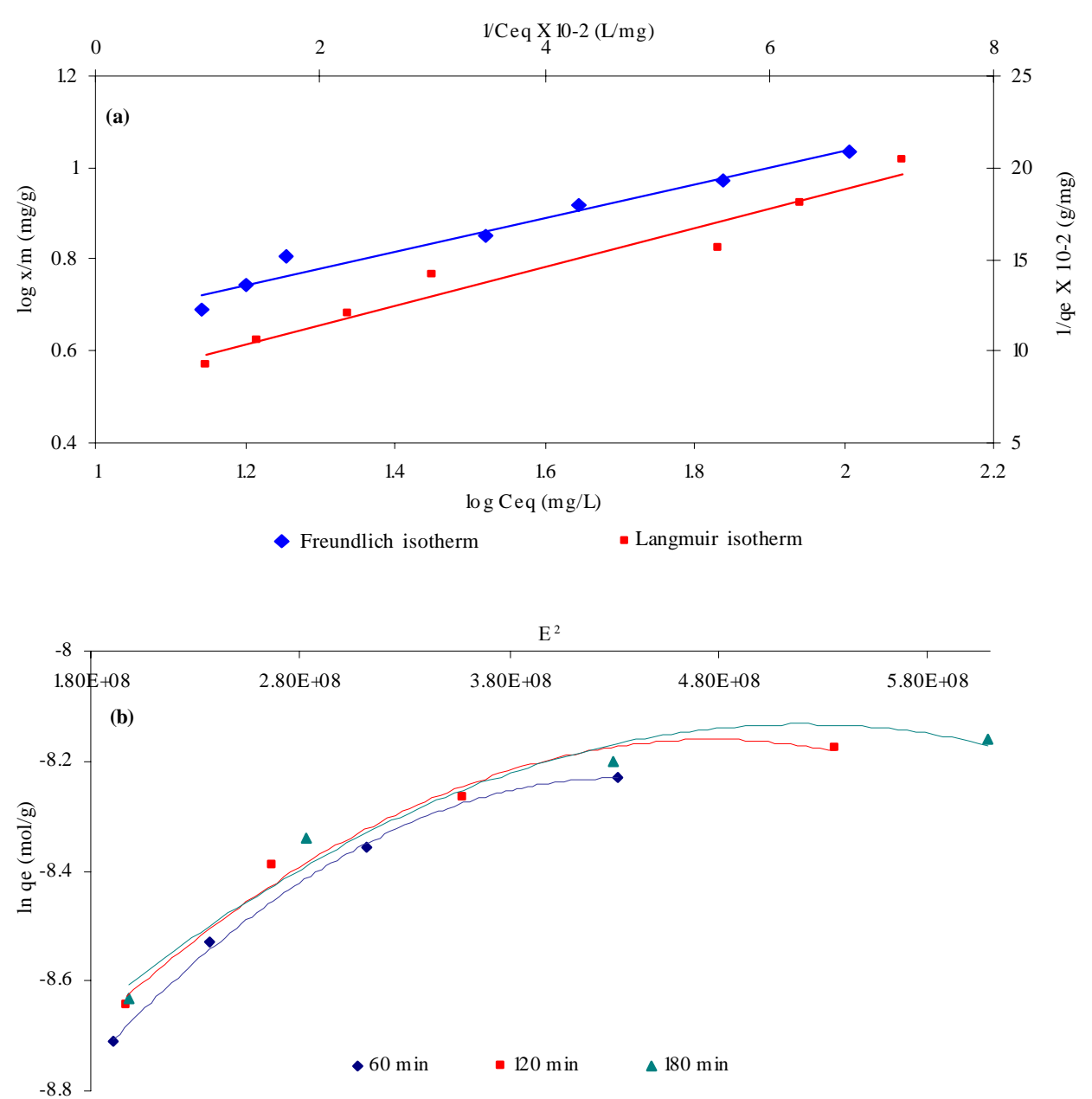

Fig. 8: (a) Freundlich and Langmuir isotherm and (b) DKR sorption isotherm

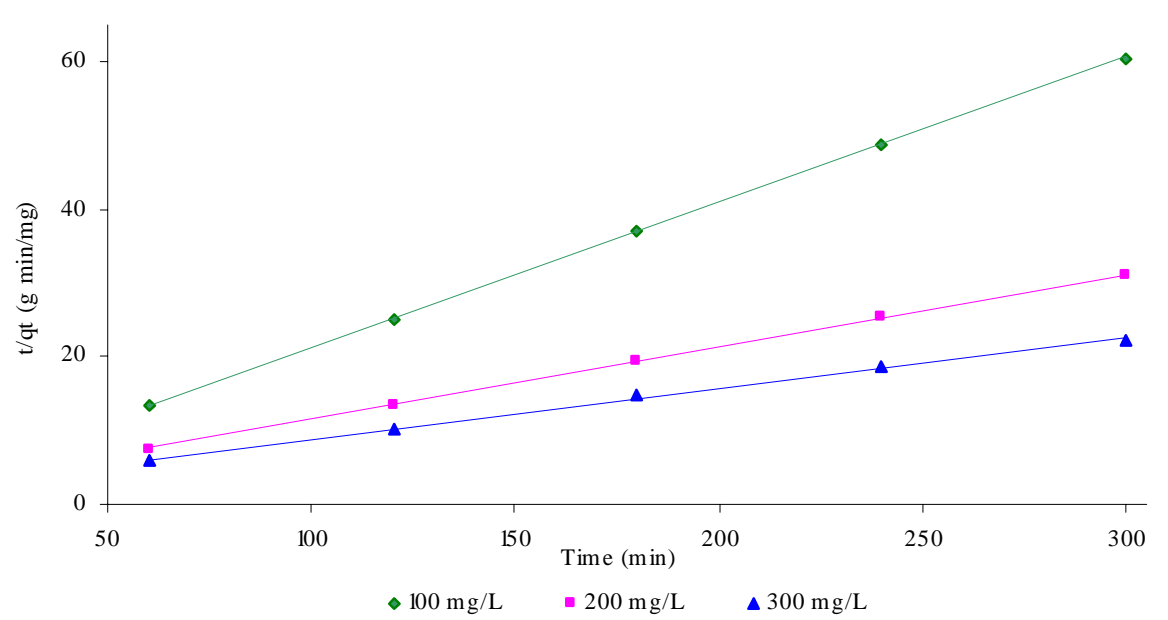

Fig. 9: Pseudo-second-order kinetic plots for removal of chromium (III) ions sorption on WBAP 
Int. J. Environ. Sci. Tech., 6 (1), 77-90, Winter 2009

Table 4: Kinetic parameters for removal of chromium (III) by WBAP (T=295 K, m=20 g/L, pH = 2.46, Stirring rate $=100 \mathrm{rpm}$ )

\begin{tabular}{|c|c|c|c|c|}
\hline \multicolumn{5}{|c|}{ Pseudo first order model } \\
\hline $\mathrm{C}_{0}(\mathrm{mg} / \mathrm{g})$ & $\mathrm{q}_{\mathrm{e}}(\mathrm{mg} / \mathrm{g})$ & $\mathrm{K}_{\mathrm{f}} \times 10^{-3}\left(\mathrm{~min}^{-1}\right)$ & $\mathrm{R}^{2}$ & \\
\hline 100 & 0.786 & 9.670 & 0.9602 & \\
\hline 200 & 2.969 & 7.599 & 0.9977 & \\
\hline 300 & 5.978 & 4.854 & 0.9827 & \\
\hline \multicolumn{5}{|c|}{ Pseudo second order model } \\
\hline $\mathrm{C}_{0}(\mathrm{mg} / \mathrm{g})$ & $\mathrm{q}_{\mathrm{e}}(\mathrm{mg} / \mathrm{g})$ & $\mathrm{h}(\mathrm{mg} / \mathrm{g} \min )$ & $\mathrm{K}_{\mathrm{s}} \times 10^{-3}(\mathrm{~g} / \mathrm{mg} \min )$ & $\mathrm{R}^{2}$ \\
\hline 100 & 5.079 & 0.6501 & 25.20 & 0.9999 \\
\hline 200 & 10.194 & 0.5726 & 5.510 & 0.9998 \\
\hline 300 & 14.514 & 0.5018 & 2.382 & 0.9982 \\
\hline
\end{tabular}

\section{CONCLUSION}

WBAP is very efficient in removal of chromium (III) from the acidic solutions/wastewater. Very short time of $15 \mathrm{~min}$ is required for the removal. The presence of other metals does not substantially influence the uptake of chromium by WBAP. The sorption process follows Freundlich sorption isotherm indicating multilayer sorption which is also evident from the SEM micrographs. The sorption process is endothermic in nature. The uptake of chromium (III) ions takes place by ion exchange. The kinetics of chromium (III) sorption process can be described by pseudo second order rate equation. Additional efforts are planned to invesigate the sorption potential of the sorbent. Thus, it could utilized for industrial wastewater treatment.

\section{REFERENCES}

Abollino, O.; Aceto, M.; Malandrino, M.; Sarzanini, C.; Mentasti, E., (2003). Adsorption of heavy metals on $\mathrm{Na}$ montmorillonite. Effect of $\mathrm{pH}$ and organic substances., Water Res., 37 (7), 1619-1627.

APHA, (1992). Standard methods for the examination of water and wastewater. $18^{\text {th. }}$ Ed., Published by American Public Health Association, Washington DC, USA.

Bessiere, J.; Chakir, A.; Kacemi, K.; Marouf, B., (2002). A comparative study of the removal of trivalent chromium from aqueous solutions by bentonite and expanded perlite., J. Hazard. Mater., 95 (1), 29-46.

Bhanot, A.; Driscoll, C.; Schwarz, J., (1984). The zero point charge of silica alumina oxide suspensions., J. Colloid Interf. Sci., 97 (1), 55-61.

Bhargava, P.; Guha, S., (2005). Removal of chromium from synthetic plating wastes by zero valent iron and sulfate reducing bacteria., Water Environ. Res., 77 (4), 411-416.

Bleam, W.; Shen, S.; Tu, S.; Taylor, R., (2000). Chromate removal by dithionate reduced clays: Evidence from direct X-ray adsorption near edge spectroscopy (XANES) of chromate reduction at clay surfaces., Clay. Clay. Miner., 48 (6), 648-654.

Burgess, B.; Corbin, D.; Faelee, R.; Vega, A., (1987). Comparison of analytical techniques for the determination of silicon and aluminum contents in zeolites., Anal. Chem., 59 (22), 2722-2728.
Choudhary, B.; Kunwar, A.; Parthasarathy, G.; Sreedhar, B.; Srinivasan, R., (2003). Ferrous saponite from deccan trap, India, and its applicatioin in adsorption and reduction of hexavalent chromium., Am. Minerologist, 88 (11-12), 1983-1988.

Cielslak-Golonka, M., (1995). Toxic and mutagenic effects of chromium (VI): A review., Polyhedron, 15 (21), 3667-3689.

Coats, A. W.; Redfern, J., (1964). Kinetic parameters from thermogravimetric data., Nature, 201 (1), 68-69.

Eckenfelder, W., (1989). Industrial water pollution control. McGraw Hill, New York.

Ekenberg, M.; Martender, H.; Walender, T., (2005). Biological reduction of hexavalent chromium - A field study. Water Environ. Res., 77 (4), 425-428.

Entezari, M. H.; Chamsaz, M., Ghows, N., (2005). Combination of ultrasound and discarded tire rubber: Removal of Cr (III) from aqueous solution., J. Phys. Chem. A, 109 (20), 46384642.

Erdem, M.; Altundogan, H.; Ozer, A.; Tumen, F., (2001). Cr (VI) reduction in aqueous solution by using synthetic iron sulfide., Environ. Tech., 22 (10), 1213-1222.

Erdem, M.; Gur, F.; Tumen, F., (2004). Cr (VI) reduction in aqueous solutions by siderite., J. Hazard. Mater., 113 (1-3), 217-222.

Freundlich, H.; Hatfield, H., (1926). Colloid and Capillary Chemistry. Methuen and Co. Ltd., London.

Gheju, M.; Lovi, A., (2006). Kinetics of hexavalent chromium reduction by scrap iron., J. Hazard. Mater., 135 (1-3), 66-73.

Ghiassi, K.; Smith, E., (2006). Chromate removal by an iron sorbent: Mechanism and modeling., Water Environ. Res., 78 (9), 84-93.

Gode, F.; Pehlivan, E., (2007). Sorption of Cr (III) onto bDAEG-sporopollenin and CEP- sporopollenin resins., Bioresource Tech., 98 (4), 904-911.

Hasany, S. M.; Ahmad, R., (2006). The potential of cost effective coconut husk for the removal of toxic metal ions for environmental protection., J. Environ. Manage., 81 (3), 286295.

Han, X.; Tam, Y.; Wong, Y., (2006). Surface complexation mechanism and modeling in $\mathrm{Cr}$ (III) biosorption by a microalgal isolate, Chlorella miniata., J. Colloid Interf. Sci., 303 (2), 365-371.

HDR Engineering Inc (2001). Handbook of public water systems. John Wiley and Sons, New York.

Ho, Y. S.; McKay, G., (1999). The kinetics of sorption of divalent metal ions onto sphagnum moss peat., Water Res., 34 (3), 735-742.

Indian Standards, (1993). Indian standard specification for drinking water: IS: 10500. 
JCPDS, (1971). Index (Inorganic) to the powder diffraction file. Joint Committee on Powder Diffraction Standards, Publication PDIS-211, Newton square, PA.

Kirk, R.; Othmer, D., (1994). Encyclopedia of chemical technology. Wiley and Sons: New York.

Kowalski, Z., (1994). Treatment of chromic tannery wastes., J. Hazard. Mater., 37 (2), 137-144.

Krishna, B.; Murty, D.; Jai Prakash, B., (2000). Thermodynamics of chromium (VI) anionic species sorption onto surfactant modified montmorillonite clay., J. Colloid Interf. Sci., 229 (1), 230-236.

Krieg, H.; Keizer, K.; Schmuhl, R., (2001). Adsorption of Cu (II) and Cr (VI) ions by chitosan: Kinetics and equilibrium studies., Water SA, 27 (1), 1-7.

Langmuir, I., (1918). The adsorption of gases on plane surfaces of glass, mica and platinum., J. Am. Chem. Soc., 40 (8), 1361-1403.

Li, Z.; Wang, T., (2004). High - temperature reduction of chromium (VI) in solid alkali., J. Hazard. Mater., 112 (1-2), 63-69.

Meunier, N.; Blais, J.; Laroulandie, J.; Tyagi, R., (2003). Cocoa shells for heavy metal removal from acidic solutions., Bioresource Tech., 90 (3), 255-263.

Natale, F.; Lancia, A.; Molino, A.; Musmarra, D., (2007). Removal of chromium ions from aqueous solutions by adsorption on activated carbon and char., J. Hazard. Mater., 145 (3), 381-390.
Shah, B. A.; Shah, A. V.; Bhandari, B., (2003). Selective elution of metal ions on a new chelating ion-exchange resin derived from substituted 8-Hydroxyquinoline., Asian J. Chem., 15 (1), 117-125.

Shah, B. A.; Shah, A. V.; Bhandari, B., (2004). Recovery of transition metal ions from binary mixtures by ion-exchange column chromatography using synthesized chelating resin derived from M - Cresol., Asian J. Chem., 16 (3-4), 18011810.

Shah, B. A.; Shah, A. V.; Shah, P. M., (2006). Synthesis, characterization, and analytical applications of O-Substituted Benzoic Acid chelating resin., Iran. Polym. J., 15 (10), 809816.

Shah, A.; Shah, B.; Singh, R., (2007). Sorption behavior of $\mathrm{Cu}$ (II) from acidic solution using Weathered Basalt Andesite Products., E-J. Chem., 4 (4), 587-605.

USEPA, (2003). List of drinking water contaminants and maximum contaminant level (EPA 816-F- 03-016). Avalable at: http://www.epa.gov/safewater/mcl.html.

USHHS, (1991). Toxicological profile for chromium. Public Health Services Agency for Toxic Substances and Diseases Registry, US Departement of Health and Human Services, Washington DC, USA.

Van Olphen, H., (1963). An introduction to clay colloid chemistry. Inter Science Publication, New York.

Vogel, A., (1989). A Textbook of Quantitative Chemical Analysis, $5^{\text {th. }}$ Ed., ELBS Publication, London.

\section{AUTHOR (S) BIOSKETCHES}

Shah, B. A., M.Sc., Ph.D., redear, Department of Chemistry, Veer Narmad South Gujarat University, Gujarat, India. Email: bhavna606@yahoo.co.in

Shah, A. V., M. Sc., Ph.D., lecturer and Head in the Science and Humanities Department, Veer Narmad South Gujarat University, Gujarat, India. Email: ajaybhavnain@yahoo.co.in

Singh R. R., Ph.D. research student in analytical chemistry, Veer Narmad South Gujarat University, Surat, Gujarat, India. E-mail: rs.chemistry@gmail.com

This article should be referenced as follows:

Shah, B. A.; Shah, A. V.; Singh R. R., (2008). Sorption isotherms and kinetics of chromium uptake from wastewater using natural sorbent material. Int. J. Environ. Sci. Tech., 6 (1), 77-90. 